AL HIKMAH RESEARCH

\& PUBLICATION CENTRE

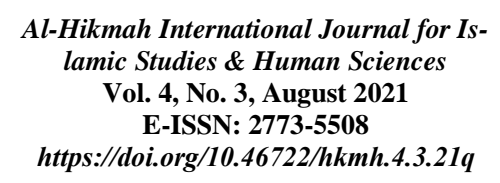

\title{
The Views of The Women Activists in Sri Lanka on The Validity of Walī in A Marriage: A Juristic Analysis
}

\author{
Mohamed Buhary Fowzul \\ Department of Islamic Jurisprudence (Fiqh and Usul al-Fiqh), \\ KIRKHS, International Islamic University Malaysia \\ fowzulbuhary@gmail.com
}

\begin{abstract}
The women activists in Sri Lanka, namely the Muslim Women Research and Action Forum (MWRAF) advocate for reform in the Muslim Marriage and Divorce Act of Sri Lanka (MMDA). Nonetheless, since the Shāfi ' 1 Madhhab is predominant in Sri Lanka, the All-Ceylon Jam-e-athul Ulama (ACJU) - the mainstream organization of the jurists in Sri Lanka refutes the demands of the MWRAF. Consequently, there has been a deadlock over the years between the MWRAF and the ACJU. Hence, this research aims to analyse the critiques of the MWRAF regarding the validity of Wali (legal guardian) in a marriage and the responses of the ACJU. Accordingly, it explores the arguments of the women activists and their justifications such as the prioritisation of the opinions of the Hanafi jurists, refusal of the Hadìths regarding the Walī and the claim that the Hadiths regarding the Wali are contradictory to the Qur'an. Moreover, it analyses the coercion of matured and unmatured bride. Since this is a juristic analysis, it draws on the Quran, the Hadiths and the opinions of the classical and the modern jurists. Finally, this research finds that the critiques of the women activists are against the majority opinion of the jurists and proves that validating the marriage without Wali cause detrimental effects in the Muslim Community of Sri Lanka. Hence, this research enlightens the women activists regarding validity of Wali in a marriage providing the persuasive evidence from the divine texts and the prominent jurists.
\end{abstract}

Keywords: Islamic Jurisprudence, Marriage, Sri Lanka, Walī, Women Activists 


\section{THE VIEWS OF THE WOMEN ACTIVISTS IN SRI LANKA ON THE VALIDITY OF WALĪ IN A MARRIAGE: A JURISTIC ANALYSIS THE DEFINITIONS OF THE WALI}

The word Wali means the guardian who safeguards the persons under his custody. In Sharī $a h$, Wali is defined as a person who is vested with legal authority to cherish the rights of other persons who are unable to decide matters independently. In the case of marriage, Wali is someone who has been authorised to contract his ward's marriage.

The jurists establish that there are two kinds of Wali. The first is 'Wali 'àm' (general guardian), who has general authority over women in a Muslim nation. Another one is 'Wali khāṣ' (specific guardian), who has exclusive authority on daughters or relatives based on blood relationships that include father, grandfather, consanguine brothers, paternal uncles, paternal nephews, among the line of inheritance sharers(al-Zuhaylī, 2012).

\section{VIEWS OF THE JURISTS REGARDING THE WALI}

There are four divergent views among the jurists regarding the authority of Walī on validating a marriage.

\section{The Incumbency of Wali for the Validity of Marriage}

Most of the jurists, including Mālik, Shāfi '̄i, Hanbalī and Zāhirī opine that Wali is an intrinsic component of marriage. Hence, consent of Wali is mandatory for validating a marriage contract, and a woman is not permitted to solemnise her marriage or others marriage (al-Jazīrī, 2003, 4|51,52).

Ibn Rushd elaborates that: "Mālik opines that there is no marriage without Wali. Because it is a stipulation for the validity of marriage" (alQurțubī, 1995, 2|9). Likewise, Shāfi 'ī stresses that: "if a woman married without a Walī, the marriage would not be valid" (Al-Shāfi ' $\overline{1}, 2001,5 \mid 13$ ). Ibn Qudāmah (1992) elaborates that: "verily, the marriage will not be validated without a Walī. The woman has no right to contract her marriage herself or other's marriage, and she cannot authorise others who are not her Wali to contract her marriage. If she does so, the marriage will not be valid".

The jurists who support this opinion draw on considerable evidence from the Qur'an and the Hadith as follows:

1. Moreover, "marry those among you who are single (i.e. a man who has no wife and the woman who has no husband) and (also marry) 


\section{Mohamed Buhary Fowzul 414}

the Salihun (pious, fit and capable ones) of your (male) slaves and maid-servants (female slaves)" (al-Nūr:32). This verse commands the guardians directly. So, this is evidence that the women are not authorised to contract the marriage without a Wali (Al-Qurțubī, 2006, 12|239).

2. "And give not (your daughters) in marriage to al-Mushrikin" (alBaqarah:221). al-'Asqalānī (9|90) elaborates that: "The Almighty Allah instruct the men to contract the marriage, but he does not command women". al-Qurțubī $(2006,3 \mid 72)$ emphasizes that: "this verse orders, in other words, ' $\mathrm{O}$ guardians, do not merry your wards off to polytheists'. Then, this verse is explicit evidence that there is no marriage without a Wali.

3. "Wed them with the permission of their folk (guardians, Awliya' or masters)" (al-Nisā':25). In this verse, the Almighty Allah instructs the men to marry the women with the permission of the bride's guardians. The Almighty did not instruct the women. Had they have any right in contracting their marriage, He would have mentioned (al-Qurțubī, 2006, 3|73).

4. "He said: I intend to wed one of these two daughters of mine to you, on condition that you serve me for eight years" (al-Qașaș:27). This verse describes that Șālih (A.S.) assigned the task of contracting the marriage of his daughter. He did not let her undertake it herself. Accordingly, al-Qurtubī emphasises that: "this verse also stresses that the contracting marriage is a duty of the guardians and there is no right for a woman in this regard. Therefore, Șālih (A.S.) undertook it.

5. "And when you have divorced women, and they have fulfilled the term of their prescribed period, do not prevent them from marrying their (former) husbands, if they mutually agree on a reasonable basis." (al-Baqarah:232).

\section{Al-Hasan narrated that:}

“Concerning the Qur'anic verse: 'Do not prevent them'(alBaqarah:232), Ma qil bin Yasar told me that it was revealed in his connection. He said, "I married my sister to a man, and he divorced her, and when her days of 'Iddah (three menstrual periods) were over, the man came again and asked for her hand, but I said to him, 'I married her to you and made her your bed (your wife) and favoured you with her, 


\section{THE VIEWS OF THE WOMEN ACTIVISTS IN SRI LANKA ON THE}

VALIDITY OF WALĪ IN A MARRIAGE: A JURISTIC ANALYSIS

but you divorced her. Now you come to ask for her hand again. No, by Allah, she will never go back to you (again)!' That man was not bad, and his wife wanted to go back to him. So, Allah revealed this verse: 'Do not prevent them' (al-Baqarah:232). So, I said, 'Now I will do it (let her go back to him), O Allah's Messenger (PBUH). "So, he married her to him again" (al-Bukhārī, Hadīth No:5130). Hence, this verse explicitly proclaims a guardian's vitality in the marriage while it asserts a woman's dependence on her guardian (al- 'Abādī, 1995, 1262).

Besides, Ibn Hajar al- 'Asqal-ānī asserts that 'this verse is explicit evidence to signify the sense of guardian. Otherwise, there is no meaning to this verse. If a woman could marry herself, the sister of Mu aqqil would not have complained to the Prophet (PBUH) (Fatḥul Bārī, Hadīth No:4529).

Moreover, the following Qur'anic verses also stress the significance of 'Wall' such as "Wed them with the permission of their folk (guardians, Awliya' or masters)" (al-Nisā':25), and "And marry those among you who are single (i.e. a man who has no wife and the woman who has no husband) and (also marry) the Sālihūn (pious, fit and capable ones) of your (male) slaves and maid-servants (female slaves)" (al-Nūr:32).

Simultaneously, there are numerous Hadith elucidating the accountability of legal guardian in solemnising the marriage as follow:

1. Abū Mūsā al-Ash 'arī (R.A.) narrated: The Prophet said, "There is no marriage without the permission of a guardian" (Abū Dāwūd, Hadīth No: 2085).

2. ' $\bar{A}$ 'ishah (R.A.) narrated: The Prophet (PBUH) said: "The marriage of a woman who marries without the consent of her guardians is void. (He said these words) three times. If there is cohabitation, she gets her dower for the intercourse her husband has had. If there is a dispute, the sultan (man in authority) is the guardian of one who has none" (Abū Dāwūd, Hadīth No: 2083).

3. Abū Hurairah (R.A.) narrated, the Prophet said: "No woman should arrange the marriage of another woman, and no woman should arrange her marriage. The adulteress is the one who arranges her marriage" (Ibn Mājah, Hadīth No:1956). 


\section{Mohamed Buhary Fowzul 416}

The above Ahādīth demonstrate that 'a woman cannot act as a guardian and cannot marry anyone without the consent of Walī. al-Shāfi ' $\overline{1}$ (2001, 6|34) highlights that: "Umar annulled the marriage of a woman who married without her Walı'.

\section{Validating the Marriage without Walī}

Nonetheless, Abū Ḥanīfah, Ibn Sīrīn, al-Sha 'abī, al-Zuhrī and Qatātah argue that a grown-up woman can contract her marriage herself. The Wali is not stipulated for her marriage, whether she is a virgin or widow (alSarkhasī, 5|12).

They pinpoint that there are great testaments in the Qur'an and the Prophetic traditions granting women the permission for solemnising her marriage herself such as:

1. "And if he has divorced her (the third time) then she is not lawful unto him, thereafter until she has married another husband (alBaqarah:230)". In this verse, Almighty Allah connects the marriage contract and the right of retrieval to the woman without mentioning the Wali. Hence, the woman has the right to contract her marriage herself without the participation of Walī (Al-Kāsānī, 2003, 373).

2. "And a believing woman if she offers herself to the Prophet, and the Prophet wishes to marry her - a privilege for you only, not for the (rest of) the believers" (al-Aḥzāb:50). This verse is explicit evidence to consider a woman's word in the marriage and its validity by her word or by offering herself (Al-Kāsānī, 2003, 372).

3. And "And when you have divorced women and they have fulfilled the term of their prescribed period, do not prevent them from marrying their (former) husbands, if they mutually agree on a reasonable basis (al-Baqarah:232)", and "there is no sin on you if they (the wives) dispose of themselves in a just and honourable manner (i.e. they can marry) (al-Baqarah:234)".

Elaborating the above Qur'anic verses, al-Sarkhasi stresses that the almighty Allah allowed the woman to solemnise her marriage without the consent of Wali. Besides, Allah has forbidden the guardians not to prevent the woman to marry themselves if the spouses are satisfied with the marriage. Eventually, the women are permissible to marry themselves (A1Sarkhasī, Vol.5, 10). 


\section{THE VIEWS OF THE WOMEN ACTIVISTS IN SRI LANKA ON THE VALIDITY OF WALĪ IN A MARRIAGE: A JURISTIC ANALYSIS}

Besides, citing the Hadìth, "The matron has more right to herself than her Wali , and the virgin is to give permission for herself, and her silence is her permission" al-Tirmidhi, Hadìth No:1108. Abū Hanīfah, Awzā' $\overline{1}$, Abū Thawr claim that this Hadìth provides the women with the power and privilege more than her Wali. Hence, she can contract her marriage herself without the consent of Wali.

Moreover, they cite the following Hadīth, "A girl came to the Prophet and said: 'My father married me to his brother's son so that he might raise his status thereby.' The Prophet gave her a choice, and she said: 'I approve of what my father did, but I wanted women to know that their fathers have no right to do that" (Ibn Mājah, Hadīth No:1947).

Similarly, Khansā' bint Khidhām narrated: "that her father gave her in marriage when she was a matron, and she disliked that marriage. So, she went to Allah's Messenger (PBUH), and he declared that marriage invalid" (al-Bukhārī, Hadīth No:5138), and the Prophet (PBUH) said: "A guardian has no concern with a woman previously married and has no husband" (Abū Dāwūd, Hadīth No:2100). Likewise, A woman solemnised the marriage of her daughter with her consent. Then the Wali (legal guardians) complained about her to 'Alī (R.A). However, 'Alī (R.A.) authorised that solemnisation (Ibn Abī Shaybah, Hadīth No:15952).

Considering the authorisation of 'Alī (R.A.) as evidence, alSarkhasī stresses that "if a woman married herself or authorised a person who is not a legal guardian for her and accordingly, he solemnised her marriage. Then marriage would be validated.

\section{Permission for Women to Contract the Marriage with the Con- sent of the Walī}

Abū Thawr and Muhammad bin al-Hasan opine that if a woman contracts her marriage or others' marriage with the consent of her guardian, the marriage will be valid drawing on the Hadith:

"The Messenger of Allah (PBUH) said: The marriage of a woman who marries without the consent of her guardians is void. (He said these words) three times. If there is cohabitation, she gets her dower for the intercourse her husband has had. If there is a dispute, the sultan (man in authority) is the 


\section{Mohamed Buhary Fowzul 418}

guardian of one who has none" (Abū Dāwūd, Hadīth No:2083).

They argue that this Hadith stipulates the consent of Wali. Therefore, this Hadith's connotation denotes that the marriage will be valid if the Wali grants permission. Because the marriage contract is suspended upon the consent of Walī (Ibn Qudāmah, 1992).

\section{Differentiation between Virgin and Widow}

However, al-Zāhirī differentiate between widow and virgin and allow the widow to contract her marriage herself without Wall s consent. But he necessitates the consent of Wali for virgin, quoting the Hadith, "A woman without a husband has more right to her person than her guardian, and a virgin's consent must be asked from her, and her silence implies her consent”" (Muslim, Hadīth No:1421).

\section{AUTHORITY OF WALĪ IN CHILD MARRIAGE}

The small boy is not aware of the mașlahah (interest) for him in the marriage and the mașlahah of his prospectus wife. Hence, the jurists prevented the participation of children themselves in their marriage contract and provided the full authority and rights to the Wali for solemnising the marriage of minor boy and minor girl with the condition of prioritising the father and grandfather to be Wali as they are aware of their children rather than others (Nawāhị̣ah and al-Mu'minī, 2010, 93).

To fulfil the benefits (mașlahah) of children, the jurists impose the following stipulations:

1. Wal̄ should be the father and not others (according to Mālik, Ahmad and numerous jurists). However, imam Shāfi ' $\overline{1}$ included grandfather with father.

2. (Mașlahah) the benefits of a minor boy and a minor girl in the marriage should be materialised.

3. The compatibility of the spouses should be confirmed. 


\section{THE VIEWS OF THE WOMEN ACTIVISTS IN SRI LANKA ON THE VALIDITY OF WALĪ IN A MARRIAGE: A JURISTIC ANALYSIS}

However, Ibn Hazm (9|458) differentiates between a minor boy's marriage and a minor girl's marriage stressing the permissibility of contracting a minor girl's marriage while nullifying the boy's marriage.

\section{COERCING THE BRIDE FOR MARRIAGE}

The coercing bride can be considered in three types: the widow (thayyib), the virgin (bikr), and the unmatured girl.

\section{Coercing the Widowed Woman for the Marriage}

There are two differing views regarding the coercion of widowed brides. Most of the jurists forbid compelling widowed women for the marriage, while others allow the forced marriage.

1. The majority opinions show the solidarity on prohibiting the forceful marriage of widowed woman as the jurists of Hanafĩ (al-Sarkhasī, 5|9), Mālikī (Ibn Rushd, 1995, 3|14), Shāfi '̄̄, (al-Shāfi '̄̄, 2001, 6|75), Hanbalī (Ibn Qudāmah, 1992, 9|406), and al-Zāhirī (11|20) proclaim their views on forbidding the coercion of those women. Therefore, Ibn Taymiyah $(2004,32 \mid 39)$ emphasises that 'it has been a consensus that no father or none can contract the marriage of a grown-up widowed woman. Ibn Hajar $(1995,9 \mid 244)$ elaborates that: "if a widowed woman married off without her consent, the marriage would be annulled based on the consensus of the jurists.

The jurists cite several Hadīth such as the narration of Khansā' bint Khidhām: "that her father gave her in marriage when she was a matron, and she disliked that marriage. So, she went to Allah's Messenger (PBUH), and he declared that marriage invalid" (al-Bukhārī, Hadīth No:5138).

Furthermore, the Prophet declared that: "The matron has more right to herself than her Wali, and the virgin is to give permission for herself, and her silence is her permission" (al-Tirmidhi, Hadīth No:1108.) and "A woman without a husband has more right to her person than her guardian, and a virgin's consent must be asked from her, and her silence implies her consent" (al-Tirmidhi, Hadīth No:1108).

2. Nonetheless, al-Hasan al-Bașarī and Ibrāhīm al-Nakha '̄i opine that the Wali can contract the marriage without the consent of his ward despite 


\section{Mohamed Buhary Fowzul 420}

her despise. In contrast, Ismā ' $\overline{1}$ bin Ishạa mentions that this is the rarest opinion that contradicts with the Sunnah and the scholars (Al-Shimrānī, 2007, 476).

\section{Coercing the Grown-up Virgin for the Marriage}

The jurists hold differing opinions in forcing the grown-up virgin. Mālikī, Shāfí $' \overline{1}$, Ibn Abī Laylā allow the Walī to solemnise the marriage without her consent whereas Abū Hanīfah, Awzā $\overline{1}$, Abū Thawr necessitate the consent of the grown-up virgin drawing on several Hadith such as the Hadith narrated by ' $\overline{\mathrm{A}}$ ' ishah (R.A.):

"A girl came to her and said: 'My father married me to his brother's son so that he might raise his status thereby, and I was unwilling.' She said: 'Sit here until the Prophet comes.' Then the Messenger of Allah came, and I told him (what she had said). He sent word to her father, calling him, and he left the matter up to her. She said: 'O Messenger of Allah, I accept what my father did, but I wanted to know whether women have any say in the matter" (al-Nasā' $\overline{1}$, Hadīth No:3269).

Furthermore, Ibn Taymiyah (2004, 32|40) elaborates that "the scholars hold divergent views on obtaining consent, whether obligatory or optional. However, it is obligatory".

Al-Baghavī asserts that:

"If there is a marriage without Wali, it would be nullified according to the Hadith "The Messenger of Allah (PBUH) said: The marriage of a woman who marries without the consent of her guardians is void. (He said these words) three times. If there is cohabitation, she gets her dower for the intercourse her husband has had. If there is a dispute, the sul$\tan$ (man in authority) is the guardian of one who has none" (Abū Dāwūd, Hadīth No:2083). Thus, this Hadīth is evidence that the marriage contract would not be a matter pending the approval of Wali (al-Baghavī 1983, 9|42).

Elaborating the Hadith narrated by ' $\bar{A}$ 'ishah (R.A.) "The Messenger of Allah (PBUH) said: The marriage of a woman who marries without 


\section{THE VIEWS OF THE WOMEN ACTIVISTS IN SRI LANKA ON THE VALIDITY OF WALĪ IN A MARRIAGE: A JURISTIC ANALYSIS}

the consent of her guardians is void. (He said these words) three times" (Abū Dāwūd, Hadīth No:2083). Imam Shāfi 'î stresses that: "the statement of the Prophet nullified the marriage contract without Wali. Hence, if that marriage is invalid, it should be reinstated by another new contract" (alShāfi '̄i, 2001).

\section{Coercing the Unmatured Girl for the Marriage}

There are two differing views on the legality of contracting the marriage of an unmatured girl.

1. The jurists of Hanafī (al-Sarkhasī, 4|212), Mālikī (Ibn Rushd, 1995, 3|17), Shāfí '̄ (al-Shāfi '̄i 2001, 6|73), Hanbalīi (Ibn Qudāmah, 1992, 9|398) and Zāhirī (Ibn Hazm, 11|20) allows the forceful marriage of an unmatured girl. Accordingly, Ibn Abd al-Barr states that: "the jurists unanimously agree that a father is authorised to contract the marriage of his unmatured daughter without her consent (Ibn 'Abd al-Barr, 1993, 16|49).
Besides, Ibn Qudāmah $(1992,9 \mid 398)$ states that:
"There are no divergent views on the marriage of an unma- tured girl as Ibn Mundhir mentions it: "all scholars whom I memorised from them consistently agree that it is permissi- ble if a father contracts the marriage of his unmatured daughter to a compatible bridegroom despite her disdain and denial".

2. In contrast, Ibn Shubrumah and Abu Bakr al-Asammu opine that: "the father is not authorised to contract the marriage of unmatured boys and girls until they attain the puberty and consent for the marriage (alSarkhasī, 4|212).

They cite the verse "And try orphans (as regards their intelligence) until they reach the age of marriage; if then you find sound judgement in them, release their property to them" (al-Nisā':06), and justify that there is no meaning to this verse if the marriage before the puberty is permissible and there is no need to contract the marriage of unmatured boy and girl. Because the main objective of the marriage is curbing the passion and reproducing the generation. Nevertheless, childhood does not cope with those intentions (al-Shimrān̄i, 2007, 472). 


\section{Mohamed Buhary Fowzul 422}

Hence, the woman activists argue that the involvement of Wali prevents the freedom of choice and other marital freedom of women and misinterpret the texts. Moreover, they criticise the veracity of Hadith, which emphasises the importance of Wali.

On the contrary, this researcher relies on the jurists' consensus, who assures the vitality of Wali in a marriage. Though the Hanafĩ Jurists hold differing views, they also accept the authority of Wali in a marriage contract.

\section{VIEWS OF THE WOMEN ACTIVISTS ON THE VALIDITY OF WALI IN A MARRIAGE}

The MWRAF first lobby for the absolute freedom in choosing a bridegroom and contracting the marriage without wali and his interference drawing on Hanafí jurists' opinions. Then, they argue that the Hadiths related to wali contradict the Qur'anic verses. Finally, they accentuate that those Hadiths are not authentic enough but weak (da îf). Hence, their arguments are analysed under the following titles.

\section{Analysis of the Opinions of Hanafĩ Jurists regarding the Walī}

When it comes to analysing the opinions of Hanafî jurists, Ibn Ābdīn states that:

"The Hadīth 'The marriage of a woman who marries without the consent of her guardians is void. (He said these words) three times. If there is cohabitation, she gets her dower for the intercourse her husband has had. If there is a dispute, the sultan (man in authority) is the guardian of one who has none' (Abū Dāwūd, Hadīth No:2083), and the Hadīth 'There is no marriage without the permission of a guardian' (Abū Dāwūd, Hadīth No:2085) contradict the Hadīth, 'The matron has more right to herself than her wali, and the virgin is to give permission for herself, and her silence is her permission"” (al-Tirmidhī, Hadīth No:1108). Al-Ayyim denotes to 'a woman who has no husband, whether she is a virgin or widow, the wali has no right to involve in her marriage except her concerns, Since the 


\section{THE VIEWS OF THE WOMEN ACTIVISTS IN SRI LANKA ON THE VALIDITY OF WALĪ IN A MARRIAGE: A JURISTIC ANALYSIS}

woman has more rights than her wall' (Ibn 'Ābdīn, 2003, $155)$.

Furthermore, al-Jașṣāṣ interprets that 'lā ta 'ḍlūhunna' in the Qur'anic verse "And when you have divorced women and they have fulfilled the term of their prescribed period, do not prevent them from marrying their (former) husbands, if they mutually agree on reasonable basis" (al-Baqarah:232) means do not prevent them or do not compel them for the marriage. So, this verse constitutes the validity of a marriage without wali and the permission of wali in two ways. First, this verse connects the contract with her regardless of the permission of her wali . Secondly, this verse forbade the compulsion or interference of the wali if the spouses agree to marry (al-Jașșāṣ, 1992, 100).

In addition to that al-Jașsāạ elaborates that the Qur'anic verse "and if he has divorced her (the third time) then she is not lawful unto him, after that until she has married another husband" (al-Baqarah:230) also allows the women to contract the marriage without the wali. Furthermore, alJașsâș deduces the evidence from the incident of a woman who gifted herself to the Prophet (PBUH). Hence, al-Jașșās stresses that the Prophet (PBUH) did not ask her whether she has walı or not and the Prophet (PBUH) also did not stipulate the wali for the validity of her marriage (alJașșāṣ, 1992, 100-104).

It was narrated from Umm Salamah that when her 'Iddah had ended, Abū Bakr sent word to her proposing marriage to her, but she did not marry him. Then the Messenger of Allah sent 'Umar bin Al-Khattab with a proposal of marriage. She said:

"Tell the Messenger of Allah that I am a jealous woman and that I have sons, and none of my guardians is present". He went to the Messenger of Allah and told him that. He said: "Go back to her and tell her: As for your saying that you are a jealous woman, I will pray to Allah for you to take away your jealousy. As for your saying that you have sons, your sons will be taken care of. And as for your saying that none of your guardians are present, none of your guardians, present or absent, would object to that". She said to her son: "O 'Umar, get up and perform the marriage to the Messenger of Allah", so he performed the marriage" (al-Nasā'î: Hadīth No:3254). 


\section{Mohamed Buhary Fowzul 424}

\section{Responses to the Interpretations of the Hanafi Jurists}

On the contrary, most of the jurists emphasise the vitality of walī. Ibn 'Abd al-Barr states that: "the Qur'an and the Sunnah explicitly constitutes that there is no marriage without wali. So, there is no meaning to which that contradicts with both the Qur' an and the Sunnah" (Ibn 'Abd al-Barr, 2008, 30).

The Hadith "The matron has more right to herself than her wali, and the virgin is to give permission for herself, and her silence is her permission" (al-Tirmidhi, Hadīth No:1108) stipulates the expression of a widow's consent concerning her marriage regardless of a virgin. Hence, this Hadīth, differentiate between widow and virgin only in the expression methods not in the stipulation of wali. Therefore, the sister of Ma'qal depended on the approval of her brother despite being a divorcee. Accordingly, al-Shäfi ' $\overline{1}$ delineates that the widow and virgin will not marry without wali . But the wali will contract the marriage with the explicit concern of his ward whereas the wali of a virgin is authorised to contract the marriage of his ward without her command. Because he has more rights on the virgin regardless of the widow.

When we delve into the deduction of Hanafĩ jurists for allowing the marriage without wali from the Qur'anic verse "And when you have divorced women and they have fulfilled the term of their prescribed period, do not prevent them from marrying their (former) husbands, if they mutually agree on reasonable basis (al-Baqarah:232)". The background incident of the same verse has a complete response to them. When her sister complained to the Prophet (PBUH) about her brother's interference in her marriage, the Qur'anic verse was revealed, and the Prophet (PBUH) explained the matter to her brother. Then, comprehending the law, her brother said to the Prophet (PBUH) 'O messenger of Allah, now I perform it' (al-Bukhārī, Hadīth No:5130). Hence, Ibn 'Abd al-Barr (2008, 25) argues that if he (Ma'qal) has not any right in the marriage contract, he would not have prohibited forcing her. Similarly, if he had no authority over her, the Prophet would not have summoned him, and he would not have told 'I perform it'.

As for their argument regarding the verse, "and if he has divorced her (the third time) then she is not lawful unto him, thereafter until she has married another husband (al-Baqarah:230)". This verse also can be under- 


\section{THE VIEWS OF THE WOMEN ACTIVISTS IN SRI LANKA ON THE VALIDITY OF WALĪ IN A MARRIAGE: A JURISTIC ANALYSIS}

stood by the background incident of the revelation. Since this Hadith lucidly elucidates the intended objective of this the Qur'anic verse. "A person divorced his wife by three pronouncements; then another person married her, and he also divorced her without having sexual intercourse with her. Then the first husband of her intended to remarry her. It was about such a case that Allah's Messenger (PBUH) was asked, whereupon he said: No, until the second one has tasted her sweetness as the first one had tasted" (Muslim, Hadīth No:1433).

Interpreting this verse, "And if he has divorced her (the third time), then she is not lawful unto him thereafter until she has married another husband (al-Baqarah:230)", al-Qurtubi $(2006,4 \mid 90)$ asserts that the word 'Nikah' denote the coitus, not the marriage, as it is interpreted by Ibn Kathīr "if a man divorces her wife the third time. Accordingly, she completed her 'Iddah, she would be forbidden for him until she marries another husband, in other words, 'until she is copulated' by another husband through a valid marriage" (Ibn Kathīr, 1999).

If we analyse the Hadith of a woman who gifted herself to the Prophet (PBUH), it is an exclusive privilege only to the Prophet (PBUH) regardless of others as the Qur'an declares it: "And a believing woman if she offers herself to the Prophet, and the Prophet (PBUH) wishes to marry her - a privilege for you only, not for the (rest of) the believers" (alAhyzāb:50). Moreover, being a ruler and a leader, the Prophet was authorised to contract the marriage of those who have no wali as the Hadith delineates it "the ruler is the guardian of the one who does not have a guardian" (Ibn Majah, Hadīth No:1953). Therefore, the Prophet (PBUH) contracted the marriage of the woman. al-Bukhārī has recorded this Hadīth under the title 'Sultan as a wall'.

When we analyse the Hadīth of Ummu Salamah,

"Tell the Messenger of Allah that I am a jealous woman and that I have sons, and none of my guardians is present", $\mathrm{He}$ went to the Messenger of Allah and told him that. He said: "Go back to her and tell her: As for your saying that you are a jealous woman, I will pray to Allah for you to take away your jealousy. As for your saying that you have sons, your sons will be taken care of. And as for your saying that none of your guardians are present, none of your guardians, present or absent, would object to that". She said to her son: "O 


\section{Mohamed Buhary Fowzul 426}

'Umar, get up and perform the marriage to the Messenger of Allah" so he performed the marriage (al-Nasā'̄i: Hadīth No:3254).

Al-Albānī states that: "this Hadīth is ḍa 'îf - not authenticated" (AlAlbān̄̄, 1985, 6|251). Besides, the command of Ummu Salamah to her son also confirms its weakness. Because her son 'Umar was two years old when she married the Prophet (PBUH). Her son was unable to understand the contract and incapable to be a wali (al-Shawkānī, 2004, 6|141). Furthermore, the narration of Ummu Salamah does not state that she married without walī. Because the Prophet (PBUH) was the wali for those who have not wali. Even if they argue that she married without wali, it may be an exclusive privilege only to the Prophet (PBUH).

Moreover, Ummu Salamah's pride imply that she was the only one who married the Prophet (PBUH) without wali. Because Almighty Allah was her wali, "When this Ayah was revealed about Zainab bint Jahsh: 'So when Zaid had completed his aim with her, we gave her to you in marriage' (al-Ahzāb:37), 'She used to boast to the wives of the Prophet (PBUH): Your families married you (to him) while Allah married me (to him) from above the Seven Heavens" (al-Tirmidhi:3519).

\section{Analysis on Refusal of the Hadīths}

The MWRAF argues that: "the Hadīths which stipulate the wali's permission are fallacious. Because the Hadīth "There is no marriage without the permission of a guardian" (Abū Dāwūd, Hadīth No:2085) is mentioned by Ibn Adi in his book 'al-Kāmil fī Du 'afā' al-Rijāl'.

Sāmir Islambolī (2001) emphasises that:

"The Hadīth which stipulate the wali for the marriage are veracious. Some of the Hadīths are prescribed in Bukharī and Muslim. Some of them are written in Sunan books. The critics of the Hadith have attested its authentication. The Hadith "there is no marriage without the permission of a guardian" (Abū Dāwūd, Hadīth No:2085) is veracious. Being mentioned in the book of Ibn Adī 'al-Kāmil fì Du 'afā' al-Rijāl' does not denote that the Hadīth is fallacious. Nonetheless, Ibn Adi prescribes it to assure that even though the 


\section{THE VIEWS OF THE WOMEN ACTIVISTS IN SRI LANKA ON THE}

VALIDITY OF WALĪ IN A MARRIAGE: A JURISTIC ANALYSIS

Hadīth has a weakness, numerous narrations rectify the Hadīth from its deficiency".

To make it crystal clear, all the Hadīth related to walī are justified below:

1. The Prophet (PBUH) said, "A matron should not be given in marriage except after consulting her; and a virgin should not be given in marriage except after her permission". The people asked, "O Allah's Messenger (PBUH)! How can we know her permission"? He said, "Her silence (indicates her permission)" (al-Bukhārī, Hadīth No:5136).

This Ḥadīth was narrated by Bukhārī and Muslim. Therefore, there is no room to challenge its authenticity.

2. 'A' ishah (R.A.) narrated: The Prophet (PBUH) said: "The marriage of a woman who marries without the consent of her guardians is void. (He said these words) three times. If there is cohabitation, she gets her dower for the intercourse her husband has had. If there is a dispute, the sultan (man in authority) is the guardian of one who has none" (Abū Dāwūd, Hadīth No:2083).

This Hadīth is authenticated by Ibn Mājah, Tirmidhī, Dāramī, Hākim, Abū Dāwūd. None of them weakened this Hadīth. Moreover, alAlbānī has attested the authentication of this Hadīth.

3. Abū Mūsā al-Ash 'arī (R.A.) narrated: The Prophet said, "There is no marriage without the permission of a guardian" (Abū Dāwūd, Hadīth No:2085).

Al-Baghawi $(1983,41)$ elaborates that: "the companions of the Prophet and their descendants implement the content of this Hadith. Accordingly, this Hadith is considered as authentic. It is the opinion of 'Umar, 'Alī, 'Abdullah Ibn Mas 'ūd, 'Abdullah Ibn 'Abbās, Abū Hurayrah, and 'A' 'ishah (R.A.)".

On the contrary, Ibn 'Adī elaborates that:

"The narration of this Hadīth through 'Abdullah Ibn 'Amr al-Wāqi' 'i has a deficiency. However, there are several other ways of narration for this Hadīth. For instance, Ibn Hibbān brings this Hadīth through the narration of 'Abd al-Rahmān 


\section{Mohamed Buhary Fowzul 428}

ibn Mahdī and attests its authentication as well as Ibn Mahdi, Alī Ibn al-Madīn̄̄ and al-Bukhārī testifies".

Furthermore, the Hadith "There is no marriage without the permission of a guardian" (Abū Dāwūd, Hadīth No:2085) was reported by Tirmidhī, Ibn Mājah, Abū Dāwūd, Bayhaqī, al-Albān̄̄, Shu ayb al-Arnaūṭ.

Al-Albānī (1985, 6|243) demonstrates that "overall, definitely this Hadīth is authenticated without any doubt. the Hadīth narrated through Abū Mūsa is authenticated by a group of imams as I am concerned".

4. Involvement of 'A' 'ishah in the marriage of her brothers' daughter.

Abū Haniffah opine that: "the engagement of ' $\bar{A}$ 'ishah in solemnising the marriage of her niece Hafșah bint 'Abd al-Raḥmān to Mundhir bin Zubayr in the absence of her father 'Abd al-Rahmān (al-Bayhaqī, Hadīth No:13652) is an explicit evidence for allowing a woman to contract others' marriage" (al-Māwardī, 1994, 9|149).

In Contrast, Shāfi' $\overline{1}$ elaborates that: ' $\bar{A}$ 'ishah arranged the marriage. but the marriage was contracted by another one except her (alShāfi ' $\overline{1}, 2001,6 \mid 33$ ), as it is reported: “' $\bar{A}$ 'ishah used to propose and testify a woman from her family. But, when the time comes to contract the marriage, she said to some of her family members: "solemnise the marriage, because the woman does not assign the marriage contract" (al-Māwardī, 1994, 9|150).

\section{Analysis on the Criticism that the Hadīths regarding the Walī are Contradictory to the Qur'an}

Moreover, women activists argue that the Hadīths, which stipulate wali, contradict the Qur'an. On the contrary, the Qur'an itself stipulates the vitality of wali in the marriage in numerous verses as follow:

1. "And give not (your daughters) in marriage to al-Mushrikin" (alBaqarah:221) commands the men to contract the marriage. It does not address women as it says in other words ' $\mathrm{O}$ guardians, do not marry your words of the atheists.

Meanwhile, Al-Qurtubi stresses that this verse is strong evidence proving that there is no marriage without wali. 


\section{THE VIEWS OF THE WOMEN ACTIVISTS IN SRI LANKA ON THE VALIDITY OF WALİ IN A MARRIAGE: A JURISTIC ANALYSIS}

2. "And when you have divorced women, and they have fulfilled the term of their prescribed period, do not prevent them from marrying their (former) husbands, if they mutually agree on a reasonable basis" (al-Baqarah:232).

The background incident of this word delineates the intended objective of this verse. Al-Hasan narrated:

"Concerning the Verse: 'Do not prevent them' (alBaqarah:232), Ma 'qil bin Yasar told me that it was revealed in his connection. He said, I married my sister to a man, and he divorced her, and when her days of 'Iddah (three menstrual periods) were over, the man came again and asked for her hand, but I said to him, 'I married her to you and made her your bed (your wife) and favoured you with her, but you divorced her. Now you come to ask for her hand again. No, by Allah, she will never go back to you (again)!' That man was not a bad man, and his wife wanted to go back to him. So, Allah revealed this verse: 'Do not prevent them' (alBaqarah:232). So, I said, 'O Allah's Messenger (PBUH), Now I will do it (let her go back to him)'. So, he married her to him again" (al-Bukhārī, Hadīth No:5130).

Al-Shāfi ' 1 , $(2001,6 \mid 33)$, emphasises that: "this is the most explicit verse in the Qur'an to prove that the wali has a considerable right on his ward as well as to prove that the wali cannot prevent his ward if she is content to marry on a reasonable basis".

Hence, Ibn Hajar stresses that: "it is authoritative evidence for considering the walì. Otherwise, there is no meaning to the word 'adl (prevention). Because if she has the right to contract her marriage herself, she did not need to rely on her brother for solemnising her marriage". Moreover, al-Qurțubī (2006, 4|104) elaborates that:

"This verse is evidence for the illegality of marriage without wali. Because the sister of Ma' qil was a divorcee, if she had the right regardless of wali, she would have contracted her marriage herself. She would not have relied on her brother's consent. Nevertheless, the verse addresses the guardians. Hence, this verse commands them to contract the marriage with the consent of the wards". 


\section{Mohamed Buhary Fowzul 430}

3. "And marry those among you who are single (i.e. a man who has no wife and the woman who has no husband) and (also marry) the Sālihūn (pious, fit and capable ones) of your (male) slaves and maid-servants (female slaves)" (al-Nūr:32).

Al-Qurțubī (2006, 4|105) states that: "Almighty Allah addresses the men to contract the marriages. if the women had the rights, he would have addressed them".

Ibn al-Sa 'dī says: "Almighty Allah command the guardians and masters to contract the marriage of those who are under their guardianship" (Al-Sa'dī, 2000).

4. "Wed them with the permission of their own folk (guardians, Awliyā or masters)" (al-Nisā'?:25).

Hence, it is evident that the Qur'an stipulate the wali as the Hadith do so. Consequently, their allegation of contradiction between Hadith and the Qur'an is denied.

However, the feminist in Sri Lanka advocates nullifying the consent of wali and allowing the women to act as wali. They stress that: "Most of the marriage among the Muslim of Sri Lanka are facilitated by the family, especially by the parents except few love marriages. Invariably, parents have the power and rights to decide on the marriages of their daughters. A field research conducted by a woman organisation intensely illustrate the background of marriage as follow:

"Several women who were interviewed said that: 'they met their husband at their wedding ceremony after the marriage registration' and some women in Colombo who teach in the slave island said that: 'they saw their husbands before the wedding only in the photos'. Some women responded that: 'they could meet once before the wedding in the houses of brides'. However, the Malay women have the freedom to select their life partner" (Faizun, 1999, 24).

Hence, Hasanah expresses her view that:

"There is no arrangement to prove the consent of brides when only the wali consented at the wedding engagement. 


\section{THE VIEWS OF THE WOMEN ACTIVISTS IN SRI LANKA ON THE}

VALIDITY OF WALĪ IN A MARRIAGE: A JURISTIC ANALYSIS

Consequently, numerous Muslim girls are forced into a marital life with whom they disagree. Hence, such marriages are most probably abandoned within a short period of marital life. Therefore, it is pertinent to amend the law to accommodate the consent of the brides. Ensuring the requirement of Islam"(Hasanah, 2015, 18).

Nonetheless, the allegations of the women activists would be meaningless in the context of Sri Lanka. In the proposed marriage, most brides meet their bridegrooms before marriage in a limited time, and probably their first meeting may be their wedding day. If it were the first meeting for the bride, it would be simultaneously the bridegroom's first meeting. This is a long-lasting tradition among the Muslims of Sri Lanka.

Likewise, there may be some forced marriage without the consent of the bride. It might be happened due to the ignorance of the guardians regarding the rulings of Islam. Because Islam explicitly establishes the consent of the bride for the marriage. Accordingly, the Prophet (PBUH) has annulled the marriage which was contracted without the bride's consent. Hence, the women activists should take measures to educate the guardians or to annul those marriages, but not to abolish the legality of wali.

Accordingly, the women activists urge to amend the law just for the few couples of love marriages. In those cases, most Muslim parents in Sri Lanka refuse the love marriages of their daughters to protect their dignity and social esteem. Sometimes, they might find that their daughter made the wrong decision choosing an incompatible life partner. Nonetheless, if they refuse to consent despite that their daughter made the right choice, the couples can resort to the $q \bar{a} d \bar{l}$ to solemnise the marriage. Thus, there is no need to nullify the wali just for supporting the exceptional cases.

Moreover, ACJU $(2017,4)$ argues that:

"Stipulation of wali in the marriage benefits the women in multiple ways. The wali act as an advisor, a guide, a mediator, a sponsor, and a guard. Therefore, he endeavours to find a compatible, morally, and socially suited person for his ward, protect her from flattery and deceit, facilitate her marriage and maintain the relationship between two families since the marriage contract is the familial and societal contract". 


\section{Mohamed Buhary Fowzul 432}

Likewise, the president of ACJU criticises that:

"The demand of women activists for the marriages without wali encourages the love marriages and the relations out of the wedlock leading to destruct the Islamic rulings as well as the family structure. Furthermore, if the young women were given free will to contract their marriage themselves, they would be misguided, deceived by the evil people" $(2017,5)$.

Overall, scrutinising the justifications and arguments regarding the wali, most jurists view that the grown-up woman should not solemnise her marriage or others' marriage since the (male) wali is the stipulation for solemnising the marriage contract. Because the involvement of wali distinguishes the Islamic marriage from the non-Islamic marriages as it is constituted by the narration of ' $\bar{A}$ 'ishah that:

"There were four types of marriage during pre-Islamic period of ignorance. One type was similar to that of the present-day, i.e. a man used to ask somebody else for the hand of a girl under his guardianship or his daughter's hand, give her mahr and then marry her. But when Muhammad (PBUH) was sent with the Truth, he abolished all the types of marriages observed in the pre-Islamic period of ignorance except the type of marriage the people recognise today" (alBukhārī, Hadīth No:5127).

Simultaneously, Abū Zahrah elucidates that:

"The majority opinion stresses the wali as a stipulation for solemnising the marriage and it does not allow the woman to consummate her marriage herself alone. In contrast, even though Abū Hanīfah provides the woman the right to contract her marriage, he authorises the wali the power of nullifying the marriage contract in case of lacking equivalence between the spouses and lacking the customary mahr (bridal gift). Hence, it is evident that both groups assert the power of wali though the way of their demonstration is distinctive" (Abū Zahrah, 1950, 129). 


\section{THE VIEWS OF THE WOMEN ACTIVISTS IN SRI LANKA ON THE VALIDITY OF WALĪ IN A MARRIAGE: A JURISTIC ANALYSIS}

Moreover, it should be noted that stipulating the wali in the marriage does not mean the coercion of brides as well as stipulating the consent of brides does not degrade the vitality of wali.

\section{Conclusion}

The MWRAF lobbies to enact the opinions of Hanafi jurists regarding the Walī. Nevertheless, the ACJU argues that the interpretations of the Hanafi jurists regarding the Quranic verses and Hadìths related to Wali are unacceptable since persuasive sources are stressing the vitality of Walī.

Likewise, the women activists argue that the Hadiths which stipulate the permission of wali are fallacious. Nevertheless, when deeply explored, it was found that though there is a deficiency in the narration of the Hadith, there are some other authenticated Hadith that stipulate the involvement of walī in a marriage.

Besides, women activists argue that the Hadiths, which stipulate wali, contradict the Quran. On the contrary, it was found that numerous Quranic verses stipulate the vitality of wali in a marriage.

Moreover, The MWRAF claim the right for women to choose their life partner as they wish, ensuring the autonomous rights of women. However, the ACJU criticises that "the demand of MWRAF for the marriage without wali encourages love marriages and relations out of the wedlock that leads to destruct the Islamic rulings and the family structure. Furthermore, if the young women were given freedom to contract their marriage themselves, they would be misguided and deceived by the evil people.

However, it was found that the parents or the guardians in Sri Lanka traditionally have more dominance on their wards that sometimes lead to a clash between them. Hence, the wali and their wards need to be enlightened about their duties and responsibilities. Then the clashes between the wali and their wards on the matrimonial matters will be wiped out. On the contrary, if the vitality of wali would be diminished, the family structure would be destroyed, and the fornications would increase among the Muslims. 


\section{Mohamed Buhary Fowzul 434}

\section{BIBLIOGRAPHY}

Abū Zahrah, M. (1950). al-Aḥwāl al-Shakhșiyyah. Beirut: Dār al-Fikr.

ACJU, A. C. J. U. (2017). Proposal for the Muslim Marriage and Divorce Act: Shariah Perspective. Colombo.

Al-Albānī, N. (1985). Irwā' al-Ghalīl fì Takhrīj Ahādīth Manār al-Sabīl. Beirut: al-Maktab al-Islāmī.

Al-Baghavī, H. M. (1983). Sharah al-Sunnah. Beirut: al-Maktab alIslāmī.

Al-Jașṣāṣ, A. bin 'Al̄̄. (1992). Aḥkām al-Quran. Beirut: Dār ihyyā alturāth al-Arabi.

Al-Jazīrī, 'Abdur Raḥmān. (2003). Kitāb al-Fiqh 'Alā al-Madhāhib alArba'ah. Beirut: Dār al-Kutub al- ilmiyyah.

Al-Kāsānī, A. B. M. (2003). Badā' 'i u al-Sanā'i '. Beirut: Dār al-Kutub al- ilmiyyah.

Al-Māwardī, 'Alī bin Muḥammad. (1994). al-Hāâwi al-Kabīr. Beirut: Dār al-Kutub al-'ilmiyyah.

Al-Qurțubī, M. A. (2006). al-Jāmi u li Aḥkām al-Quran. Beirut: alRisālah Publishers.

Al-Sarkhasī, S. (n.d.). al-Mabsūṭ. Beirut: Dār al-Ma rifah.

Al-Sa 'd̄̄, 'Abd al-Raḥmān bin Nāṣir. (2000). Taysīr al-Karìm al-Raḥmān fì Tafsīr Kalām al-Mannān. Riyadh: Mu'assasat al-Risālah.

Al-Shāfi ì, M. I. (2001). al-Ummu. Mansoura: Dār al-Wafā. http://www.kinandkids.com/premarital-counseling-what-everyengaged-couple-think-they-dont-need-what-every-married-couplebelieve-they-do/

Al-Shawkānī, M. bin 'Alī. (2004). Nayl al-Awțār. Beirut: Bayt al-Afkār al-duwaliyyah.

Al-Shimrānī, Șāliḥ bin 'Alī. (2007). al-Aqwāl al-Shādhdhah fì Bidāyat al-Mujtahid li Ibn Rushd. Riyadh: Maktabat Dār al-Minhāj.

Al-Zuhaylī, W. (2012). Mawsū'at al-Fiqh al-Islāmī wa al-Qaḍ̂yā alMu 'ạsarah. Damuscus: Dār al-Fikr. 
435 THE VIEWS OF THE WOMEN ACTIVISTS IN SRI LANKA ON THE VALIDITY OF WALĪ IN A MARRIAGE: A JURISTIC ANALYSIS

Al- 'Abādī, 'Abdullah. (1995). Sharah Bidāyat al-Mujtahid wa Nihāyat al-Muqtașid. Beirut: Dār al-Salām.

'Ābdīn, I. (2003). Raddu al-Mukhtār 'Alā al-Durr al-Mukhtār. Riyadh: Dār 'Ālam al-Kutub.

Hasanah, C. I. (2015). Islāmiya nokkil pālnilay samattuvam matrum sama nīthi. Colombo: A.J.printers.

Ibn Ḥajar al-'Asqalān̄̄, A. bin 'Ali. (1995). Fath al-Bārī bi Sharaḥi Șah̄ị al-Bukhārī. Beirut: Dār al-Fikr.

Ibn Ḥazm al-Ẓāhirī, 'Ali ibn Aḥmad. (n.d.). al-Mahallī. Beirut: Dār alFikr.

Ibn Kathīr, I. ibn 'Umar. (1999). Tafsīr al-Quran al- 'Ażīm. Riyadh: Dār Taybah.

Ibn Qudāmah, 'Abdullah bin Aḥmad. (1992). al-Mughnī. Cairo: Hajar.

Ibn Rushd al-Qurțubī, M. A. (1995). Bidāyat al-Mujtahid wa Nihāyat alMuqtașid. Beirut: Dār Ibn Ḥazm.

Ibn 'Abd al-Barr, Y. 'Abdullah. (1993). al-Istidhkār. Beirut: Dār Qutaybah.

Ibn 'Abd al-Barr, Y. 'Abdullah. (2008). al-Tamhīd. Beirut: al-Fārūq alHadīthiyyah.

Nawāhiḍah, I. A., \& Al-Mu'min̄̄, A. M. (2010). al-Ahwāal alShakhșiyyah Fiqh al-Nikāh. Oman: Dār al-Masīrah.

Sāmir Islambolī, M. N. (2001). Tahrī̄r al- 'Aql min al-Naql. Damuscus: Dār al-Awāyil. http://www.bayanelislam.net/Suspicion.aspx?id=0303-0040\&value=\&type=\#_edn 1 